\title{
Hausnarketa partekatuan oinarritutako praktikak: egoera errealen azterketa irakasleen prestakuntzako practicumean
}

Nerea Agirre García nagirre@mondragon.edu

Ahots Lejardi Plaza ahotslp@gmail.com

Agurtzane Martínez Gorrotxategi amartinez@mondragon.edu

Berrikuntza eta esku-hartzea hezkuntza inklusiboan ikerlerroa Humanitate eta Hezkuntza zientzien fakultatea Mondragon Unibertsitatea

Elena López de Arana Prado

Didaktika eta Eskola Antolakuntza

Hezkuntza eta Kirol Fakultatea Euskal Herriko Unibertsitatea UPV/EHU

elena.lopezdearana@ehu.eus

Mariam Bilbatua Pérez

Berrikuntza eta esku-hartzea hezkuntza inklusiboan ikerlerroa Humanitate eta Hezkuntza zientzien fakultatea

Mondragon Unibertsitatea mbilbatua@mondragon.edu

DOI: http://dx.doi.org/10.1387/tantak.17666

GAKO-HITZAK: Unibertsitate-hezkuntza, irakasleen hasierako formakuntza, practicuma, hausnarketa partekatua, tutorearen laguntzak, ikaskuntza-komunitatea. 


\section{SARRERA}

Ezagutzaren gizartearen garapenak ekarritako aldaketek behartzen gaituzte etengabe planteatzera zein diren egungo jendartean bizi ahal izateko beharrezko konpetentziak; batez ere, dimentsio ugari dituzten eta perspektiba ezberdinetatik erantzun beharreko arazo konplexuei aurre egiteko. Horretarako, zenbait autorek (Morin, 2009; Delors, 1996; Perrenoud, 2012; Hargreaves eta Shirley, 2012) beharrezkoa ikusten dute konpetentzia berrien garapena; ezagutzaren erreprodukzio hutsa gainditzen duten konpetentziak hain zuzen: sormenarekin, pentsamendu kritikoarekin, komunikazio eta elkarlanarekin, auto-erregulazioarekin, motibazioarekin eta konpromisoarekin, besteak beste, lotura daukatenak. Ingurumari honetan eskolak eta irakasleriak ikaste-prozesuetan duten eginkizunaz etengabeko hausnarketa batean murgildurik aurkitzen gara. Ondorioz, behar horietatik eratorrita, gaur egun hezkuntza-ikerketarako eremu garrantzitsua osatzen dute irakasleriaren profil profesionalak nola bere prestakuntzaren oinarrian egon beharko liratekeen printzipio metodologikoek.

Zenbait autore, hala nola arestian aipatutakoak, saiatu izan dira ikaskuntza sustatzeko irakasle-konpetentziak ezaugarritzen. Helburu berdinaz, beste azterlan batzuek fokoa kalitatezko irakasleen berariazko konpetentzietan jarri izan dute; eta autore horiek, konpetentzia garrantzitsuenen artean, norbere praktikaren gainean gogoeta egiteko gaitasuna (Esteve eta Alsina, 2010; Macdonald eta Shirley, 2009; Perrenoud, 2004) azpimarratzen dute; eta baita hezkuntza-prozesuan inplikatutako pertsonen artean inplikazio afektiboa sortzearen garrantzia ere (Day, 2006).

Ezagutza teorikoaren eta praktikoaren arteko lotura gauzatu dadin goian aipatutako konpetentziak garatzea ezinbestekoa bada ere, zenbait ikerketak, oinarri teoriko eta metodologiko oso ezberdinak izan arren, bat egiten dute irakaslegaiek eguneroko egoera praktikoak interpretatzeko erabiltzen duten ezagutza, unibertsitatean ikasitako ezagutzaren ezberdina dela esatean (Clandinin, 1986; Clarà eta Mauri, 2010; Elbaz, 1981; Korthagen 2010a; Perrenoud, 1996; Pozo, Scheuer, Mateos eta Perez Echevarría, 2006; Schön, 1983). Berariaz, irakasleek beren praktiketako esperientzia eta bizipenetatik eraikitzen duten ezagutza globala, inplizitua, dilematikoa, multidimentsionala, hitzez adierazteko zaila eta karga emozionalduna izan ohi da. Unibertsitatean ikasitako ezagutza akademikoak, berriz, oso izaera ezberdina dauka. Halaber, teoriaren eta praktikaren arteko loturek ez dute zertan beti erraztu egoeraren interpretazioa (Schön, 1983).

Aurreko baieztapenek adierazten duten moduan, irakaslegaiek ikastetxeetan izandako esperientziek eta bizipenek beren formakuntzan eta ondorioz beren praktika eta esku-hartzeetan duten eragina handiagoa da unibertsitateko ikasketek dutena baino. Honek esan nahi du irakaslegaiek jaso duten ezagutza akademikoak inpaktu txikia duela hauek ikastetxeetan bi- 
zitako egoerekiko egiten dituzten interpretazioetan eta ondorioz egoera horien ebazpenean. Irakasleak oro har, eta bereziki hasiberriak, praktikan gehiago zentratzen dira frustrazioa, beldurra eta noraeza bezalako sentimendu edo sentsazioak kontrolatzen unibertsitatean ikasi duten hori aplikatzen baino (Hammerness, Darling-Hammond, Brandsford, Berliner, Cochran-Smith, McDonald eta Zeichener, 2005; Wideen, Mayer-Smith eta Moon, 1998).

Beste ikerketa batzuek erakutsi dute (Korthagen, 2010) irakasleek ikastetxeetan duten jokabideek gehienbat jatorri irrazionalak edo inkontzienteak dituztela. Ideia horrek bat egiten du Pérez-Gómez-en (2010) ekarpenarekin. Izan ere, autore horrek azpimarratzen du ezagutza praktikoaren eraikuntzaren konplexutasuna ulertzeko dimentsio arrazionala ez dela nahikoa azpimarratzen du, eta adierazten du ikaste esperientzietako alderdi kontzienteen eta inkontzienteen arteko interakzioak ulertu behar direla.

Baieztapen hauek kolokan jartzen dute ezagutza akademikoaren lanketa, hau da, lanketa teorikoak irakasleen formakuntzaren ardatza izan behar duelakoa edo lanketa teorikoak irakasleen formakuntzaren ardatza izan behar duelako ideia. Honek esan nahi du ezinbestean formakuntzak ikuspegi holistikoagoa izan beharko lukeela, ikas-irakas prozesuetan irakasleen alderdi profesionala eta pertsonala integratuko dituena. Contreras, Monereo eta Badia-ren hitzak (2010) hartuz irakasleen prestakuntzak eraginkorra izateko irakaslegai pentsatzeko, esateko, sentitzeko eta egiteko moduan eragin behar dugu; alegia irakaslearen identitatean eragin behar dugu.

Ikerketa hauek irakasleek euren praktiketan bizi dituzten egoerekiko egiten dituzten interpretazioetan ezagutza akademiko eta praktikoaren arteko elkarrekintza nola gauzatzen den oraindik ezezaguna izaten jarraitzen duen gaia dela ondorioztatzera eraman gaituzte, eta beraz, ikerketaren eremuan arreta handiagoa merezi duen afera.

Oro har, aipatutako ikerketen emaitzek agerian uzten dituzte irakasleek ezagutza teoriko eta ezagutza praktikoaren artean harremanak eraikitzeko dituzten zailtasunak. Irakasleen prestakuntzarekin lotutako proposamen eta metodologia berriek ez dute ekarpen esanguratsurik egin irakasleentzat beharrezkoak diren ezagutza moduen eraikuntzan. Kasu gehienetan ezagutza teorikoa ezagutza praktikoari gainjarri izan zaio, edo eta ezagutza mota batetik besterako transferentzian (ezagutza teorikotik praktikora, edo alderantziz) oinarritutako irizpideak erabili izan dira, eta ez ezagutza bien arteko elkarrekintza ardatz dutenak (Mauri, Clarà, Colomina eta Onrubia, 2016).

Aurkeztu den egoera multzo honi erantzun nahirik, eta irakasleen ezagutzaren eraikuntzaren afera hobeto ulertu asmoz, irakasleek praktikan bizitako egoerei buruzko hausnarketa irakasleen prestakuntzaren ardatz gisa kokatu izan dute zenbait autorek (Gelfuso eta Dennis, 2014; Kortha- 
gen, 2001; Korthagen, 2010; Schön, 1983). Saiakera asko egin dira irakaslegaiek praktiketan bizitako egoera errealekiko interpretazioak unibertsitatean landu eta ezagutza akademikoarekin lotzeko (Korthagen, 2010b; Orland-Barak eta Yinon, 2007; Pozo eta al., 2006) eta saiakera horiek aztertuta zenbait ikerketak azpimarratu dute ezagutzaren garapenerako irakaslegaiek praktiketan bizitako egoera errealekiko taldean egindako hausnarketa prozesuek, alegia hausnarketa partekatuan oinarritutako prozesuek duten potentzialitatea. Bereziki praktiketako errealitatearekiko ulermen konplexuago izateko eta teoria eta praktikaren arteko zubiak eraikitzeko (Hammerness, Darling-Hammond, Brandsford, Berliner, Cochran-Smith, McDonald eta Zeichener, 2005; Goodwin, 2002).

Hausnarketarako espazioak sortzeak, baldintza egokiekin burutuz gero, irakasleek praktikako egoerak interpretatzeko ezagutzaren erabilera sustatzen du (Mauri, Clarà, Colomina, Onrubia eta Ginesta, 2013). Guri, irakaslegaien prestakuntzaz arduratzen garen neurrian, hausnarketarako espazio horietan teoria eta praktikaren arteko loturak nola gauzatzen diren hobeto ulertzen laguntzen digu horrek; eta baita praktikako egoeren gaineko interpretazioak egitean ezagutza mota bien (teorikoa eta praktikoa) artean, egon daitezkeen loturak nolakoak diren ulertzen ere.

Hemen aurkezten den berrikuntza esperientziak, irakasleen ezagutzaren izaera hobeto ulertu eta hausnarketarako eremuak sortzea izan du xede. Hausnarketa-eremuak ezaugarritzeko garaian alderdi hauek hartu dira aintzat: batetik, irakasle graduetako Practicumeko ikasleek berek praktikan bizitako egoera zehatzetan ardazturiko hausnarketa izatea; bestetik, egoeren gaineko hausnarketa taldean egitea; eta azkenik, elkarlanean buruturiko jardueraren ondoriozkoa izatea. Beraz, Korthagen (2001-2010), Gelfuso (2016) eta Dennis (2014) autoreekin bat eginaz, irakaslegaiak hausnarketalanetan trebatzeari heldu genion, beren praktikako egoerak ikuspegi global, multidimentsional eta dilematiko gisa (Dewey, 1989; Gelfuso eta Dennis, 2014; Mauri, Clarà, Colomina, eta Onrubia, 2013) eraikitzen eta interpretatzen lagunduz.

\section{BERRIKUNTZA ESPERIENTZIAREN TESTUINGURAKETA}

Lan honetan Bartzelonako Unibertsitateak, Sevillako Unibertsitateak eta Mondragon Unibertsitateak parte hartzen duten ikerketa proiektu baten ardatza den berrikuntza-esperientzia aurkezten da. ${ }^{1}$

1 Proiektuaren izena: EDU13-44632-P(MINECO): Agirre, N.; Bilbatua, M.; Clarà, M.; Colomina, M.R.; Anna Ginesta, A.; Jiménez, O.; López de Arana, E.; Martínez, A.; Mauri, T.; Onrubia, F.J.; Toledo, B. eta Usubiaga, A. (2013). Ayudas a la construcción del conocimiento en el practicum de maestros: la reflexión conjunta para la mejora de la relación teoría-práctica. [Ikerketa txostena]. Barcelona: Universitat de Barcelona. 
Berrikuntza-proposamena irakasle izateko graduetako Practicumeko ikasleek beren esperientziatik abiatuz, praktikan bizitako egoera errealen gaineko kasu-azterketan oinarritzen da.

Unibertsitate mailan ikasleek praktikarekin eta beraien praktikaz ikasteko esku-hartze-estrategia eraginkorrenen artean tutoreen laguntzaz egindako hausnarketa aipatzen dute zenbait ikerlarik (Korthagen, 2001; Schön, 1992). Hori dela eta, tutoreek irakasle izateko prestatzen dauden ikasleei eskainitako laguntzak izan dira ikerketa proiektu honen foku nagusietako bat.

Irakasle-graduetako Practicumeko ikasleak hamabost pertsona inguruko lantaldeetan batzen dira mintegietan elkarrekin lanean aritzeko. Hausnarketa mintegi-saioak tutore bikote batek dinamizatzen ditu; beren funtzio nagusia da ikasleek bizitako egoera praktikoen eta halako egoeretan ikasleen jardunaren inguruan hausnarketa sustatzea, orientatzea eta laguntzea da. Ikasleek mintegiaren aurretik beren praktiketako egunerokotik eztabaidara ekarri nahi duten gertakari esanguratsu bana aukeratu behar izaten dute. Gertakari horretan haiek bizi izandako hezkuntza esku-hartzeak jasotzen dituzte; hots, ikasleek beren esku-hartze propioan jartzen dute arreta (ikasleengana hurbiltzeko eta ikasleekin harremanetan jartzeko moduetan, ikasleak ulertzeko eta ikusteko moduetan, komunikazioan erabiltzen dituzten baliabide eta estrategietan, egoera ezberdinei aurre egiterako orduan berengan sortzen diren dilema eta arazoetan...) eta egoeraren narrazio literala egiten dute (protagonisten arteko elkarrizketak, deskribapen datu zehatzak...) ostean mintegietan taldearekin partekatu eta elkarrekin egoeraz hausnartzen dute. Halako egoeren irakurketatik abiatuta, egoeraren eta egoerak biltzen dituen irakasle praktikarekin lotutako alderdi ezberdinen inguruko elkarrizketa irekitzen da taldean tutoreek bideratuta.

Ikasleak protagonista diren egoeren gainean beraien errepresentazio eta ezagutza propioa eraikitzea da helburua; zehatzago esanda, taldean azaldutako egoeretako hezkuntza-testuinguruen aniztasuna aztertzea, kasuan kasuko berezitasunak eta hezkuntza beharrak identifikatzea da, hezkuntza bera testuinguru jakin batean kokaturiko fenomeno sozial gisa aitortuz (Martínez, 2011). Berdinen arteko interakzioek, ikaskideen artean eraikitako diskurtsoak, batak besteari egindako ekarpenek eta, finean, elkar elikatzeak praktikaren hobekuntzan (Tang Keow Ngang et al., 2014) eta garapen profesionalean (Manouchehri, 2002) eragin zuzena duela aztertu dute hainbat ikerlanek.

Ikasleek taldean beren esku-hartze propioen gainean hausnartzen dute. Honi dagokionez Day-ren (2005) teoriarekin bat egiten dugu, zeinetan baieztatzen duen ekintza eta ekintzaren gaineko azterketa funtsezko gakoak direla konpetentzia profesional eta pertsonalen garapenerako, bere praktikaren bidez ikasteko konpetentziak etengabe garatuko dituen profe- 
sional hausnartzaile eta konprometituak hezteko (Monereo, Monte, 2011; Korthagen, 2010) .

Hausnarketa prozesu horiek taldean gertatzen dira; irakasle graduko ikasleek prozesu dialogiko batean parte hartzen dute, beste ikasle eta egoerekin elkarreraginean, teoriaren eta praktikaren artean loturak bilatuz. Beraz, esan daiteke ikerketa-ekintzan oinarritutako ikaste jarduera bat diseinatzen dela, non talde testuinguru bat eratzen den eta tutoreak arakatze estrategia zehatzak erabiliz bideratzen duen prozesu hori (Martínez 2011; Mauri, Clarà, Colomina, Onrubia, eta Ginesta, 2013). Talde hausnarketek argudiatuak eta dokumentatuak izan behar dute ikasleek praktikaren gaineko kontzientzia hartu, interpretazioak egin eta hausnarketen nahiz eskuhartzeen kalitatea berrikusi ahal izateko (Porlán, 1987; Schön, 1998). Izan ere, hausnarketa partekatuek ikasleei aldaketaren norabidea eraikitzen laguntzen die; hau da, beren errepresentazio eta esku-hartzeak zein norabidetan aldatu edo hobetu behar dituzten identifikatzen laguntzen die (Fullan, 2002a). Alegia, praktikan burututako ekintzak ulertu, horien gainean hausnartu eta esku-hartzea berregiten lagunduko luke prozesu honek (Clarà eta Mauri, 2010).

Aldaketa horiek esanahiaren eraikuntza-prozesuan taldearen parte hartzearen ondorio dira. Wenger-ek (2001) ezagutza praktikoa aldatzeko aukera komunitate bateko partaide izatearekin lotzen du. Partaide sentitzeak aldaketarako beharrezkoak diren parte hartze aukerak eskaintzen ditu: besteekin elkarrekintzan aritzea, norbere eta komunitatearen irudia eraikitzea nor garen, nondik gatozen, non gauden eta norantz goazen irudikatu ahal izateko eta gizartean indarrean dauden printzipioekiko postura hartu eta norberaren jarduera aipatutako printzipioen arabera interpretatzea. Irakaslea, norbanako gisa, sistema sozial baten parte da (Martínez, 2011) non taldeko kideekin elkarlanean eta bereziki tutorearen laguntzaz aldaketaren zentzua eraikitzen joango den. Esan daiteke, beraz, berdinkideen arteko interakzioa eta tutoreen laguntzak hausnarketa sakonak burutzeko funtsezko baldintzak direla (Gelfuso y Dennis, 2014).

\section{IKERKETA METODOLOGIA}

\section{Lagina}

Berrikuntza prozesua martxan izanda, prozesuaren gaineko ikerketarako hartu den fokuetariko bat tutoreek ikasleei eskainitako laguntzak izan dira. Ikerketa-metodoari dagokionez kasu-azterketa (Yin, 1989) burutu da. Hiru Unibertsitateetako zortzi kasu aztertu dira (112 ikasle eta 8 irakaslek hartu dute parte): 3 kasu Bartzelonako Unibertsitatekoak izan dira, beste 3 Mondragon Unibertsitatekoak eta beste 2 kasu Sevillako Unibertsitatekoak. 1h 30 minutuko iraupeneko bost hausnarketa-saioz osatu da kasu ba- 
koitza, non irakasle graduko ikasle taldeak praktiketan bizitako egoera jakinen gainean hausnarrean aritu diren tutoreen laguntzaz. Prozesua hiru unibertsitateetan eskaintzen den Lehen Hezkuntza eta Haur Hezkuntzako Irakasle Ikasketa Graduetako Practicumean gauzatu da. Artikulu honetan Mondragon Unibertsitateko 3 kasuen datuak aurkezten ditugu. Guztira, 3 tutore eta 35 ikasle. Tutore bat kasu bakoitzeko eta talde bakoitzean 1013 ikasle inguru.

\section{Metodologia}

\subsection{Neurriak}

Artikulu honetan Mondragon Unibertsitateko 3 kasuetako bakoitzean egin ziren bost hausnarketa mintegi-saioetako bideo-erregistroen azterketa aurkeztuko da. Bideoz jasotako datuak transkribatu eta edukien azterketaren bidez analizatu ziren batetik, arreta tutoreek emandako laguntzetan jarriz. Bestetik, elkarrekintza-moduen analisia (Coll, Onrubia, eta Mauri, 2008) ere egin zen talde hausnarketa antolatzeko erabiltzen ziren estrategien identifikazioan zentratuz. Tutoreek eskaintzen zituzten laguntza diskurtsiboak aztertzeko 23 laguntza motaz osatutako kategoria sistema bat garatu zen ikerketa-taldean, hiru multzo nagusitan banatuta: 1) parte-hartzea sustatzeko laguntzak (tutoreak erabiltzen dituen laguntzetatik elkarrizketa dinamizatzeko izaera duten laguntza motak jasotzen dira multzo honetan), 2) interpretazioa sustatzeko laguntzak (tutoreak erabiltzen dituen laguntzetatik hausnarketan sakontzeko izaera duten laguntza motak jasotzen dira multzo honetan), eta 3 ) teoriaren eta praktikaren arteko lotura sustatzeko laguntzak (tutoreak erabiltzen dituen laguntzetatik ezagutza akademikoaren eta praktikoaren arteko loturak sustatzeko izaera duten laguntza motak jasotzen dira multzo honetan).

\subsection{Prozedura}

Ikerketa hau Practicum ikasgaian burutu zen. Ikasgai hau irakasle graduko ikasketa-planean baitan kokatzen da. Ikasgai honek barne hartzen ditu ikasleek ikastetxeetan burutzen dituzten praktika egonaldiak eta fakultateko tutoreekin unibertsitatean burutzen dituzten hausnarketa mintegisaioak; azken hauetan kokatzen den ikaste ekintza izan da ikerketa honetako aztergaia.

Mondragon unibertsitateko 3 kasu aztertu dira. Kasu guztietan ikasleak eta tutoreak parte hartu dute mintegi-saioetan. Ikerketan parte hartu duten ikasleak irakasletza graduko laugarren eta azken urtean egon diren ikasleak izan dira, alegia, irakasle izateko formakuntzaren azken ur- 
tean dauden irakaslegaiak. Tutoreak irakasleen formakuntzan eta practicumeko gaietan adituak izan dira. Bost hausnarketa-mintegitan izandako jardunak jaso eta aztertu dira. Guztietan ikasle kopurua 10-13 ikasle bitartekoa izan da eta tutore bi egon dira talde bakoitzarekin hausnarketamintegi bakoitzean. Saio hauek ordubete eta erdiko iraupena izan dute gutxi gorabehera. Saio horietan aztertu diren egoerak ikasleen bizipenetan oinarritutakoak izan dira; guztira, 5-7 egoera bitarte aztertu dira kasu bakoitzean.

Ikasleek beren praktikaldian bizitako esperientziak izan dira egoera horiek. Ikasleei eskatu zaie, praktikaldiak iraun duen bitartean jaso dituzten egunerokoak arakatu eta praktikaldian bizi izan dituzten egoera esanguratsuak identifikatzeko, narrazio eran jasotzeko beren esku-hartzearen zehaztasun guztiekin eta egoeran gertatzen ziren elkarrizketen transkripzio literalekin. Egoera horiek hausnarketa-mintegietan irakurri dituzte ikasleek eta horietatik abiatuta ikasleen artean elkarrizketa sortu da tutoreek gidatuta. Alegia, egoeren inguruan hausnarketa sustatu da; hausnarketa partekatuan oinarritutako mintegi- saioak izan dira. Mintegi-saio guztiak grabatu eta transkribatu dira, eta ostean datu analisia egin aipatutako kategoria sisteman oinarrituta.

\section{DATUEN AZTERKETA ETA IKERKETA EMAITZAK}

Mondragon Unibertsitatean aztertutako 3 kasuetan mintegi-saioetan tutoreek irakasle izateko prestatzen dauden ikasleei praktiketan bizitako egoera errealen inguruan hausnartzeko erabilitako laguntzak aztertu ditugu.

1. grafiko multzoan ikus dezakegu tutoreek kasu bakoitzean erabili duten laguntza kategoria bakoitzaren ehunekoa: 


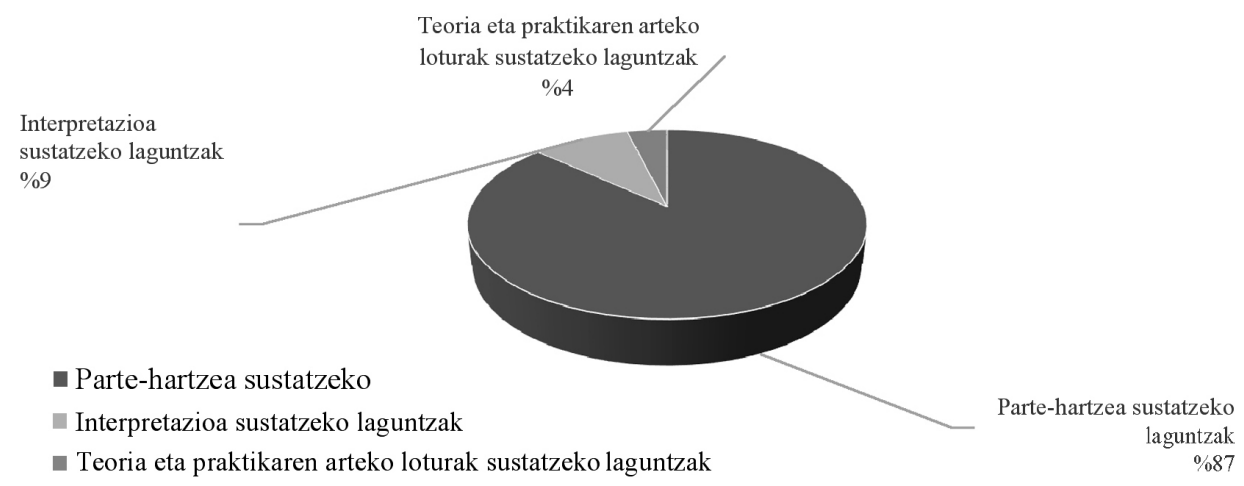

Laguntza motak (1. kasua)

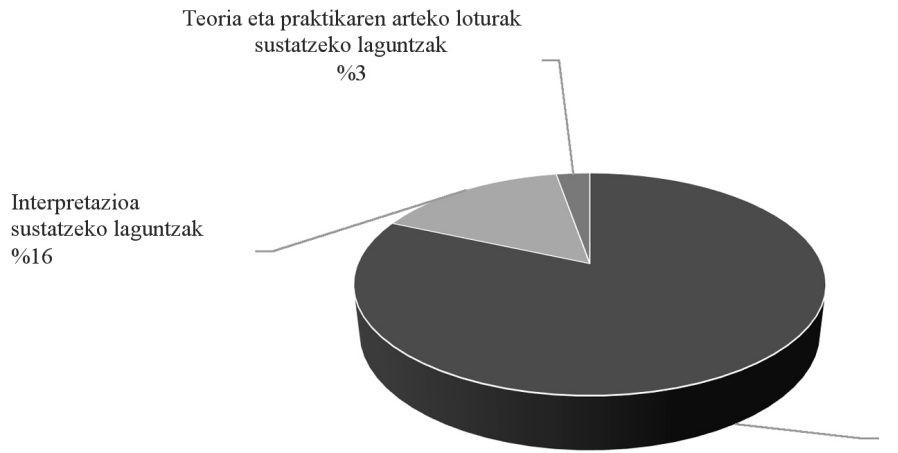

- Parte-hartzea sustatzeko

Parte-hartzea sustatzeko

- Interpretazioa sustatzeko laguntzak

- Teoria eta praktikaren arteko loturak sustatzeko laguntzak

\section{Laguntza motak (2. kasua)}

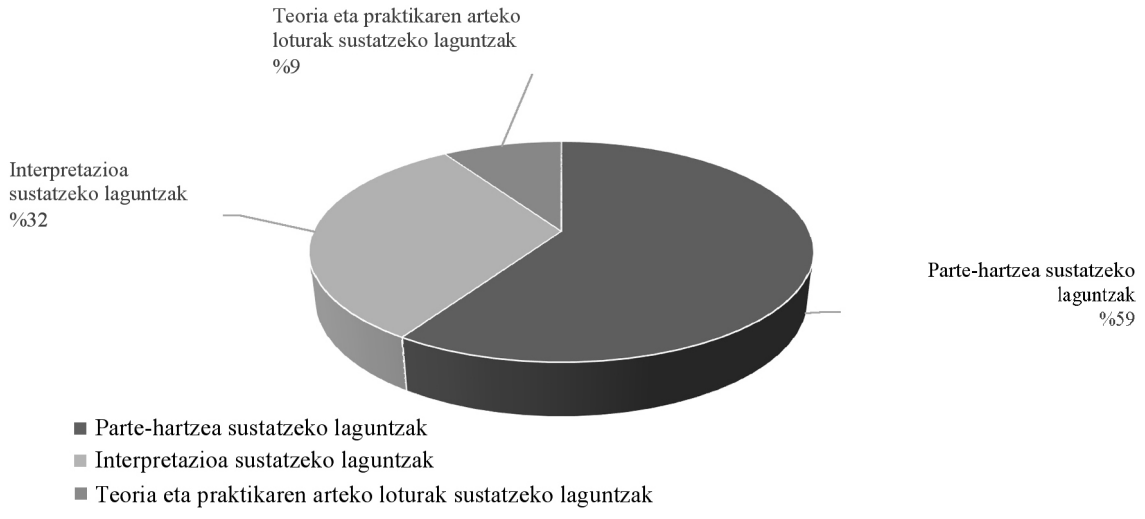

Laguntza motak (3. kasua)

1. grafiko multzoa: tutoreek erabilitako laguntzak 
1. taulan ikus ditzakegu kasu bakoitzean tutoreek nagusiki erabilitako laguntza motak eta bakoitzaren adibideak agerpen kopuruaren arabera, goitik behera zerrendatuta:

\section{1. taula}

Tutoreek kategoria bakoitzean gehien erabilitako laguntzak eta dagozkien adibideak

\begin{tabular}{|c|c|}
\hline \multicolumn{2}{|r|}{ 1. kasua } \\
\hline $\begin{array}{c}\text { Parte } \\
\text { hartzea / } \\
\text { Parte-hartzea } \\
\text { sustatzeko } \\
\text { laguntzak }\end{array}$ & $\begin{array}{l}\text { - Ikasle taldean elkarrizketa irekitzea. } \\
\text { (Adb. Zer iritzi duzue eskolako zuzendaritzatik erabaki hori hartzeari bu- } \\
\text { ruz?) } \\
\text { — Elkarrizketan egindako ekarpena osatzeko ikasle bati eskatzea. } \\
\text { (Adb. Ze motatako informazioa daukazu ikasle horrekiko baieztapen hori } \\
\text { egiteko? Sakondu dezakezu?) } \\
\text { - Ikasleen ekarpenak aintzakotzat hartzea. } \\
\text { (Adb. Zure ekarpenetan, Iker, alderdi ezberdinak azpimarratu dituzu: esko- } \\
\text { lako kultura, zuzendaritzaren inplikazioa...) }\end{array}$ \\
\hline $\begin{array}{c}\text { Interpretazioa } \\
\text { sustatzeko } \\
\text { laguntzak }\end{array}$ & $\begin{array}{l}\text { - Egoerari buruzko hausnarketan aldagai berriak txertatzeko ikasleak anima- } \\
\text { tzea. } \\
\text { (Adb. Egoera ulertzeko hainbat elementu aipatu dituzue. Zer beste alderdi } \\
\text { gehitu ditzakegu?) } \\
\text { — Egoeraren azterketarako gakotzat zehaztu den aldagaia gogoraraztea. } \\
\text { (Adb. Arazoaren gakoa familian dagoela esan baduzue, eremu horretan lan } \\
\text { egin beharko genuke...) } \\
\text { — Egoeraren interpretaziorako zehaztutako markoa zein den gogoraraztea. } \\
\text { (Adb. Gu orain hobekuntza proposamenak aztertzen ari gara; zer egin de- } \\
\text { zakegun akatsen aurrean. Ikusi behar dugu ikasleen akatsak ikaskuntzaren } \\
\text { motorra diren. Zuek ikusi behar duzue nola ulertzen dituzuen akatsak, zein } \\
\text { markotatik ulertzen dituzuen eta nola jokatuko duzuen zuen ikasleen aka- } \\
\text { tsen aurrean. Horretako ikaste testuinguruak beste modu batean antolatu } \\
\text { beharko ditugula pentsatu beharko duzue, aukeretan oinarrituta...) }\end{array}$ \\
\hline $\begin{array}{c}\text { Teoria eta } \\
\text { praktikaren } \\
\text { arteko loturak } \\
\text { sustatzeko } \\
\text { laguntzak }\end{array}$ & $\begin{array}{l}\text { - Beste egoera batzuekin loturak egitera ikasleak animatzea. } \\
\text { (Adb. Egoera honetan identifikatzen duzue ezer beste eguneko Juanen ka- } \\
\text { suarekin zerikusia duenik? } \\
\text { — Ezagutza akademikoarekin loturak egitera ikasleak animatzea. } \\
\text { (Adb. Irakasleak egiten duena zigortzea da. Gauza asko dakizue zigorra- } \\
\text { ren erabilerari buruz, errefortzuei buruz... Zer ikasi duzue beste materietan } \\
\text { honi buruz, zerekin du zerikusia?) }\end{array}$ \\
\hline
\end{tabular}




\begin{tabular}{|c|c|}
\hline \multicolumn{2}{|r|}{ 2. kasua } \\
\hline $\begin{array}{l}\text { Parte } \\
\text { hartzea / } \\
\text { Parte-hartzea } \\
\text { sustatzeko } \\
\text { laguntzak }\end{array}$ & $\begin{array}{l}\text { - Elkarrizketan egindako ekarpena osatzeko ikasle bati eskatzea. } \\
\text { (Adb. Ikasteari buruz ari zara. Zuk nola ulertzen duzu ikaste prozesua?) } \\
\text { — Ikasle taldean elkarrizketa irekitzea. } \\
\text { (Adb. Egoera horretan kokatuta, nola irudikatzen duzue Anek esan duena? } \\
\text { Itxaso zer diozu zuk?) } \\
\text { - Ikasle baten ekarpenak aintzakotzat hartzea. } \\
\text { (Adb. Eiderrek egin duen ekarpen hori oso interesgarria da. Goazen ikustera.) }\end{array}$ \\
\hline $\begin{array}{c}\text { Interpretazioa } \\
\text { sustatzeko } \\
\text { laguntzak }\end{array}$ & $\begin{array}{l}\text { - Egoerari buruzko hausnarketan aldagai berriak txertatzeko ikaslea anima- } \\
\text { tzea. } \\
\text { (Adb. Metodologia aipatu duzue. Baina ze beste elementuk izan dute era- } \\
\text { gina ikaslearen jokabidean?) } \\
\text { - Egoeraren interpretaziorako marko berria proposatzea. } \\
\text { (Adb. Ebaluazioa irakasleak ikasleen jarraipenerako erabiltzen duen tres- } \\
\text { natzat ikusten duzu. Zergatik ez hartu ebaluazioa ikuspegi hezigarri batetik } \\
\text { ikasleei euren ikaste prozesuan hobetzen laguntzeko?) }\end{array}$ \\
\hline $\begin{array}{l}\text { Teoria eta } \\
\text { praktikaren } \\
\text { arteko loturak } \\
\text { sustatzeko } \\
\text { laguntzak }\end{array}$ & $\begin{array}{l}\text { - Beste egoera batzuekin loturak egitea. } \\
\text { (Adb. Nekaneren egoerarekin antzekotasunak ditu kasu honek.) }\end{array}$ \\
\hline \multicolumn{2}{|r|}{ 3. kasua } \\
\hline $\begin{array}{l}\text { Parte } \\
\text { hartzea / } \\
\text { Parte-hartzea } \\
\text { sustatzeko } \\
\text { laguntzak }\end{array}$ & $\begin{array}{l}\text { - Ikasle taldean elkarrizketa irekitzea. } \\
\text { (Adb. Oihanek zerbait esan du gai honen inguruan. Oihane, zurea da hi- } \\
\text { tza.) } \\
\text { - Elkarrizketan egindako ekarpena osatzeko ikasle bati eskatzea. } \\
\text { (Adb. Zuk ikasle horrekin beldurra sentitu duzula esan duzu, ez? Zergatik?) }\end{array}$ \\
\hline $\begin{array}{c}\text { Interpretazioa } \\
\text { sustatzeko } \\
\text { laguntzak }\end{array}$ & $\begin{array}{l}\text { - Egoerari buruzko hausnarketan aldagai berriak txertatzera ikasleak anima- } \\
\text { tzea. } \\
\text { (Adb. Haurra ondo sentitzeko espazio seguruaz hitz egin duzue. Ze beste al- } \\
\text { derdi edukiko dugu kontutan ikasleekin harreman sare positiboak eraikitzeko?) } \\
\text { - Egoeraren interpretaziorako zehaztutako markoa zein den gogoraraztea. } \\
\text { (Adb. Taldean lan egiteaz, hitz egin duzue, aniztasunari erantzuteko talde } \\
\text { kooperatiboen erabileraz. Talde kooperatiboetan ari garenean elkarrekin } \\
\text { eta elkarrengandik ikasteko espazio eta testuinguruen erabileraz ari gara.) }\end{array}$ \\
\hline $\begin{array}{l}\text { Teoria eta } \\
\text { praktikaren } \\
\text { arteko loturak } \\
\text { sustatzeko } \\
\text { laguntzak }\end{array}$ & $\begin{array}{l}\text { - Beren esperientzia pertsonalekin loturak egitera ikasleak animatzea. } \\
\text { (Adb. Ikasle hauen artean gatazka egoera baten aurrean aurkitu zara. Zuek } \\
\text { arazoak dituzuenean nola konpontzen dituzue?) } \\
\text { - Ezagutza akademikoarekin loturak egitera ikasleak animatzea. } \\
\text { (Adb. Talde antolaketaz ari gara. Zer dakizue taldean lan egitearen ingu- } \\
\text { ruan? ze teknika edo ze estrategia metodologiko ikasi dituzue?) }\end{array}$ \\
\hline
\end{tabular}


2. taulan ikus ditzakegu kasu bakoitzeko tutoreek hausnarketaren fase bakoitzean erabilitako laguntza moten batezbestekoak:

2. taula

Tutoreek hausnarketaren fase bakoitzean erabilitako laguntzen batezbestekoak

\begin{tabular}{|c|c|c|c|c|c|}
\hline \multicolumn{6}{|c|}{ 1. kasua } \\
\hline & $\begin{array}{l}\text { Elementuen } \\
\text { argitzean }\end{array}$ & $\begin{array}{c}\text { Kasuaren } \\
\text { azterketan }\end{array}$ & $\begin{array}{l}\text { Kasuaren } \\
\text { azterketan } \\
\text { sakontzean }\end{array}$ & $\begin{array}{c}\text { Elementu } \\
\text { esanguratsuetan } \\
\text { fokalizazioan }\end{array}$ & Interpretazioan \\
\hline $\begin{array}{l}\text { Parte hartzea / Par- } \\
\text { te-hartzea sustatzeko } \\
\text { laguntzak }\end{array}$ & $\% 68$ & $\% 54$ & $\% 64$ & $\% 50$ & $\% 56$ \\
\hline $\begin{array}{l}\text { Interpretazioa susta- } \\
\text { tzeko laguntzak }\end{array}$ & $\% 25$ & $\% 20$ & $\% 26$ & $\% 27$ & $\% 28$ \\
\hline $\begin{array}{l}\text { Teoria eta praktikaren } \\
\text { arteko loturak susta- } \\
\text { tzeko laguntzak }\end{array}$ & $\% 7$ & $\% 25$ & $\% 9$ & $\% 22$ & $\% 15$ \\
\hline \multicolumn{6}{|c|}{ 2. kasua } \\
\hline $\begin{array}{l}\text { Parte hartzea / Par- } \\
\text { te-hartzea sustatzeko } \\
\text { laguntzak }\end{array}$ & $\% 90$ & $\% 73$ & $\% 76$ & $\% 76$ & $\% 71$ \\
\hline $\begin{array}{l}\text { Interpretazioa susta- } \\
\text { tzeko laguntzak }\end{array}$ & $\% 9$ & $\% 19$ & $\% 22$ & $\% 19$ & $\% 22$ \\
\hline $\begin{array}{l}\text { Teoria eta praktikaren } \\
\text { arteko loturak susta- } \\
\text { tzeko laguntzak }\end{array}$ & & $\% 4$ & $\% 2$ & $\% 3$ & $\% 6$ \\
\hline \multicolumn{6}{|c|}{ 3. kasua } \\
\hline $\begin{array}{l}\text { Parte hartzea / Par- } \\
\text { te-hartzea sustatzeko } \\
\text { laguntzak }\end{array}$ & $\% 50$ & $\% 52$ & $\% 57$ & $\% 66$ & $\% 51$ \\
\hline $\begin{array}{l}\text { Interpretazioa susta- } \\
\text { tzeko laguntzak }\end{array}$ & $\% 30$ & $\% 37$ & $\% 41$ & $\% 28$ & $\% 30$ \\
\hline $\begin{array}{l}\text { Teoria eta praktikaren } \\
\text { arteko loturak susta- } \\
\text { tzeko laguntzak }\end{array}$ & $\% 10$ & $\% 11$ & $\% 2$ & $\% 11$ & $\% 6$ \\
\hline
\end{tabular}


Datuen analisia egitean, kasu bakoitzaren barruan taldeko hausnarketa antolatzerako orduan errepikakorrak diren alderdiak ikusi dira. Hau da, tutore bakoitzak hausnarketa saioaren hasiera, garapena eta itxiera antolatzeko moduan nahiz hausnarketa prozesuan zehar erabili izan dituen laguntzei dagokionean errepikatzen diren patroiak daude. Baina ez da berdina gertatzen kasuak beren artean konparatuz gero.

Kasuen muinetara sartuz gero, hausnarketaren garapenean ikasleek ekartzen dituzten egoera praktikoen gaineko azterketa ezberdin planteatzen du tutore bakoitzak. Ezberdintasun esanguratsuenak teoria eta praktikaren arteko loturak egiterako orduan aurkitu ditugu bereziki.

Lehenengo kasuan, ikasleek ekarritako egoera praktikoak ukitzen dituen elementuak argitzetik abiatzen da hausnarketa; ondoren, egoeran eragin duten elementuak identifikatu eta aztertzen dira, eta horren ostean elkarrizketak taldea eramaten du antzeko egoeren aurrean egingo lituzkeen esku-hartzeak planteatzera. Tutoreek elementu edo adibide batean arreta jarri eta interpretazio marko berri batean fokua jartzera eramaten dute taldea, marko berrian kokatuz eztabaida birbideratuz. Ostean, tutoreek ezagutza teorikoen erabilera sustatzen dute egoera ikuspegi zabalago batetik ulertu dezaten ikasleek, eta agertzen dituzten iritzi eta ideien argudioak mahaigaineratu ditzaten. Saioari itxiera emateko aztertutako elementuen sintesia egiten da taldekide guztien artean, eta saioan zehar egindako ikaskuntza eta izandako parte-hartzearen balorazioak jasotzen dira partaideen ahotik.

Bigarren kasuan, taldeko hausnarketa hasierako azterketa orokor baten bidez irekitzen da, egoera praktikotik urruntzen diren gai ezberdinei ere leku eginaz. Horren ostean, tutoreak egoera ukitzen duten elementuen gaineko azterketa sakonago batera bideratzen du taldea. Ondoren, egoera ulertzen laguntzen duten hipotesien formulaziora bideratzen da elkarrizketa, edo fokua gehiago zehazten da eztabaida interpretazio marko zehatz batetik abiatuta birkokatuz. Orokorrean, tutorearen aldetik datozen galderen erantzun ematea dator, planteatu den egoera ebazteko asmoz. Amaieran, lehenengo kasuan bezala, elementu nagusien inguruko laburpen bat osatzen da taldean eta saioaren balorazioa egindako ikaskuntza eta izandako parte hartzearen gainean.

Hirugarren kasuan, talde eztabaida egoeraren elementuen argitzetik abiatzen da. Kasu honetan ez da identifikatu egitura argirik egoera praktikoaren azterketa nola egiten den deskribatzeko; tutoreak modu ezberdinak baliatzen ditu azterketaren helburuari erantzuteko.

Adierazgarria da bost saiotatik hirutan eztabaidaren fokalizazioa marko interpretatiboren amaiera aldera agertzen dela, eta, honi jarraikiz, tutorearen interpretazioa azaltzen dela. Saio batzuetan, azken ekintza honi taldean izaten den eztabaida edo debateak ematen dio segida.

Taldeko hausnarketa prozesuan zehar tutoreek ikasleei eskainitako laguntzei dagokienez kasutik kasura ezberdintasunak ikusi ditugu eman diren laguntza mota, maila, banaketa eta egitura-lanari dagokionez. 
Hiru kasuek ekarpen ezberdina egiten diote hausnarketa produktibo deiturikoari (Dewey, 1989). Gure kasuetan, tutoreen laguntzak bideratu dira ikasleei hasiera batean zehaztugabeak eta ulergaitzak zaizkien eta barne-kontraesanak edo korapiloak sortzen dizkieten egoerak, hausnarketaprozesuaren amaieran, zehatzak eta ulergarriak bilakatzera. Prozesu hau da hain zuzen ere Dewey (1986), Shön (1987) eta Wertheimer (1971) hausnarketaren funtziotzat ulertzen zutena eta Clarà-k (2015) haien lanak aztertuz definitu zuena; alegia, hasieran argia inkoherentea edo zentzugabea zirudien egoera bati koherentzia eta zentzua ematea.

Ondorio gisa, beraz, tutoreek talde-hausnarketaren garapenean duten garrantzia baieztatua ikusi dugu (Harford eta MacRuairc, 2008; Gelfuso eta Dennis, 2014). Eta gure ikerketaren emaitzek erakutsi digute tutoreek hausnarketa prozesuak sustatzeko orduan ematen dituzten laguntzak aldez aurretiko ezagutzekin edo esperientziekin nola teoriarekin eta ikerketekin loturak egitera bideratuta egon behar dutela, bide honek beraien praktika modu esanguratsuagoan egokitzen lagunduko baitie ikasleei edo irakaslegaiei (Berliner, 1988).

Tutoreen esku-hartzea eta erabilitako laguntzak irakaslearen beraren esku-hartze estiloekin zuzenki lotuta daudela ikusi dugu. Lehenengo bi kasuetan izaera induktiboagoaz eta taldeko kide guztien parte hartzera bideratuago egon dira; laguntzak teoria eta praktikaren arteko loturak egitera animatzen duten izan dira, faktoreen identifikaziora bideratutako laguntzak eta parte hartzea sustatzeko laguntzak. Kasu hauetan badirudi tutoreak ikasleek egoeraren gainean dituzten ideia eta ikuspuntu espontaneoekiko sentikortasun gehiago agertzen dutela. Hirugarren kasuan berriz, estilo deduktibo eta zuzentzaileagoa ikusi dugu, non interpretazio markoen identifikazioari lotutako laguntzek, eta tutorearen beraren ekarpenek pisu gehiago hartzen duten.

Amaitzeko, emaitza hauen azterketatik ondorioztatu dezakegu ildo honi lotutako ikerketarekin jarraitzeak berebiziko garrantzia duela hausnarketa-testuinguru aproposak sortzean; batetik, tutoreak hausnarketaren gainean duen kontzeptualizazioak tutorearen praktikan eragina duen jakiteko, eta bestetik, praktika horrek zer-nolako eragina duen ikasleek egiten duten hausnarketa motan aztertzeko. Praktika honi lotuta, tutorearen laguntzak ikasleen hausnarketa prozesuak sustatu ahal izateko, hausnarketa prozesuan zehar azaltzen diren beharrei egokitu behar zaizkiela azpimarratzen dute zenbait lanek (Van de Pol, Volman eta Beishuizen, 2010). Beraz, alderdi hauek ikertzeak hausnarketa prozesuan planteatu beharreko ikuspegia argitzen lagunduko liguke, eta ikasleen aldetik izaera multidimentsional eta dilematikoa (Clarà eta Mauri, 2010; Mauri, Clarà, Colomina, Onrubia eta Ginesta, 2013; Rivas, Leite eta Cortés, 2011) duen hausnarketa sustatzeko praktika zehatza ezaugarritzen. 


\section{ONDORIOAK}

Unibertsitateko tutoreon lanari dagokionez, ikerketari esker tutoreon jarduna modu sistematikoan jaso ahal izan dugu, eta hausnarketa prozesuak errazten dituzten laguntzen izaera ezaugarritu dugu. Baina hau aurrera eramateko antolaketa eta lan dinamiketan ere arreta jarri nahi dugu. Izan ere, hemen aurkeztu dugun ikerketa-lanetara eta emaitzetara iristeko laguntzen gaineko azterketa tutore taldean modu partekatuan egin dugu; tutoreon lan dinamika ere hausnarketa partekatuan oinarritu da taldean hobekuntza eta berrikuntzarako estrategiak (Hord, 1997; Krichesky eta Muri1lo, 2011; Stoll eta Louis, 2007) martxan jarriz, eta Ikaskuntza Komunitate Profesionala eratzen hasiz.

Ikerketan parte hartu dugun eta Ikaskuntza Komunitate Profesionaleko partaide garen irakasle eta ikerlariok gure praktikaren inguruan ikerketa prozesuak martxan jartzeak, benetako eragin eraldatzailea duela sinesten dugu; izan ere, prozesu hauek dialogikoak dira, kontrastean oinarrituak, kezkak eta kontraesanak azaleratzen dituztenak, eta honek ahalbideratzen digu ekintza indibidualak ekintza kolektibo bilakatzea, aldaketaren eragina handituz. Gainera, uste dugu, honek laguntzen duela praktikan eta berau sortzen den testuinguru eta baldintzetan sakoneko aldaketak integratzen (Liston eta Zeichner, 1993; Pérez, 1992; Pérez, Barquín eta Angulo, 1999).

Esperientzia honek Haur Hezkuntzako eta Lehen Hezkuntzako graduetako zenbait zeregin modu kolektiboan berregiten lagundu digu; egoera praktikoak ikasleak praktikak egiten dituen testuinguru lokalei lotuago ulertzen, aldaketarako kultura sustatzen eta elkarlanean oinarritutako antolaketa-ereduak ezartzen unibertsitate eremuan, irakasletzako titulazio akademikoetan eraginaz, eta ondorioz etorkizunean gure eskoletan eragiteko esperantzaz.

Aldaketa koherente eta eraginkorrak bideratu ahal izateko beharrezkoa iruditzen zaigu esperientziaren sistematizazioa; hartara, ezagutza eraikitzeko eta transferitzeko. Gainera, esperientzia honetan egin bezala, praktika garatzen den errealitatetik eta bertan sortzen diren beharretatik abiatzeak esangura handiagoa du. Halaber, lantaldearen eta erakundearen barruan gauzatzen diren ikaskuntza mekanismoak ulertzeak ekarpena egin digu; honek gure kultura profesionala ezagutzeko aukera gehiago ireki baitaizkigu, eta horrela, modu kolaboratiboago baten hezkuntza proiektu sendoagoa proiektatu ahal izan dugu.

Ondorioz, berrikuntza- eta ikerketa-esperientzia honek eraman gaitu ikaskuntza hausnartzailea oinarri duten ikaste testuinguruak diseinatzera, zeinak ekintzan zentratuak, ekintzaren gainean eraikiak, eta ekintzarekin lotuak baitaude (Day, 2005); talde-testuinguruan eta ikerketa-ekintzan oinarrituta (Orcasitas, 2005). Horren harira, geure egiten dugu honako ideia: ez da posible luzaroan ikasleen ikaskuntza eraginkor baterako baldintzak 
sortu eta mantentzea, aldi berean ez bada irakasleen garapen profesionalerako baldintzarik erdiesten (Bolivar, 2008).

Ikerketak irakasle-ikasketetako practicumaren planteamenduan eta tutoreek jokatzen duten paperean aldaketak egon direla azaleratu du. Planteamendu metodologikoetan argi ikus daiteke practicum irakasgaian aldaketak egon direla, ikasgaia ikerketa-ekintza parte hartzailean oinarrituriko metodologian ardaztu izanak erraztu du taldean hausnartutako ezagutzaren gaineko eraikuntza; ezagutza hausnartua, esanguratsua eta kolaboratiboa. Aurretik aipatu dugun bezala, praxiak eta hausnarketak elkarren eskutik joan behar dute sakoneko ikaskuntza eman dadin. Planteamendu metodologikoak Wenger-en (2001) ideia jasotzen du, zeinak ikaskuntza gure ekintzak besteen ekintzekin batera elkarreraginean jartzetik eratortzen dela esaten duen. Beraz, ikaste-emaitzak sozialki eraikiak dira (Lave eta Wenger, 1991) eta ekintzaren gaineko hausnarketatik ikaskuntza erator dadin hau beste eragile batzuekin partekatua izan behar da.

Hortaz, esan daiteke ikerketan parte hartu duten irakasleek diseinaturiko ikaste testuingurua Ikaskuntza Komunitate Profesional baten eraikuntzan hezurmamitu dela, non ikasleek beren esperientzia praktikoa taldean aztertu eta hobetzen duten, eta beren etorkizuneko lanbidea modu hausnartzailean irudikatzen duten, halako moduz non, (pixkana-pixkana,) irakasle-soslaiari berariaz lotutako konpetentziak garatzen baitituzte.

Helburu bikoitzaz jarduten dugula esan daiteke, honenbestez. Batetik, Ikaskuntza Komunitateak ikasleei beraien esperientzia praktikoa taldean aztertu eta hobetzeko aukera eskaintzen die. Izan ere, hausnarketa partekatuak aldaketaren norabidea eraikitzen laguntzen die ikasleei; hau da, errepresentazio eta esku-hartzeak zein norabidetan aldatu edo hobetu behar dituzten identifikatzen laguntzen die (Fullan, 2002b). Aldaketa horiek esanahiaren eraikuntza-prozesuan taldearen parte hartzearen ondorio dira. Nolanahi ere den, «esanahiaren eraikuntza» nahiko finkatua dago jakintzaarloan (Martínez, 2011), non taldeko kideekin elkarlanean eta tutorearen laguntzaz aldaketaren zentzua eraikitzen joango den. Praktikan bizi izan dituzten egoeren gaineko hausnarketa elkarlanean egiten da eta, hausnarketak bide itxia jarraitu barik, elkarlanean buruturiko jardueraren ondoriozkoa izatea bilatzen dugu.

Eta bestetik, etorkizuneko lanbidea modu hausnartzailean irudikatzen duten bitartean, etengabeko ikaskuntzarekin nahiz ikaskuntza komunitateen sorkuntzarekin lotutako konpetentziak-irakasle profil berariaz lotutako konpetentziak- garatzea dugu helburu. Ikasleekin batera komunitateen eraikuntzarako gakoak identifikatuz eta lanaren dinamizazio eta jarraikortasunerako estrategiak eskuratuz.

Beraz, ikasleek hausnarketa partekatuan oinarrituriko egoera sozialen gaineko ezagutza indibiduala eraiki ahal izan dute; eta aldi berean etenga- 
beko ikaskuntzaz nahiz ikaskuntza komunitateen sorkuntzarekin lotutako konpetentziak garatu ahal izan dituzte, zeregin hauek hezkuntza-berrikuntzaren eta -hobekuntzaren esparruan kokatuz.

Jasotze-data: 2017/01/12

Onartze-data: $2017 / 06 / 20$

\begin{abstract}
This innovation experience aims the contribution to establish reflection's scopes for understanding teachers' knowledge nature and create contexts for joint reflection: a) encouraging students' reflection about real cases happened during the practicum; b) designing collaborative reflective formats for these cases involving both: students and tutor; c) promoting reflection ensues/keeps the collaborative activity process.
\end{abstract}

Keywords: University education, initial teacher training, practicum, collaborative reflection, teacher's aids, community of practice.

La experiencia de innovación presentada pretende contribuir a establecer ámbitos de reflexión conjunta que propicien relaciones entre el conocimiento práctico y el conocimiento académico en la formación inicial del profesorado: a) propiciando la reflexión de los estudiantes en el practicum centrada en analizar casos de situaciones reales de su práctica; b) estructurando formatos de reflexión colaborativa de las situaciones entre los estudiantes y con su tutor; c) favoreciendo que la reflexión siguiera un proceso resultante de la actividad colaborativa.

Palabras clave: Educación universitaria, formación inicial del profesorado, practicum, reflexión colaborativa, ayudas del profesor, comunidades de práctica.

L'expérience présentée prétend contribuer à établir des champs de réflexions pour comprendre la nature du savoir des professeurs. L'expérience innovante prétend contribuer à établir des pistes de réflexions pour comprendre l'origine des compétences du professeur : a) en encourageant la réflexion des étudiants dans l'exercice de l'analyse de cas pratique ; b) en structurant une forme de réflexion 
collective à partir des problèmes vécus par les étudiants et encadré par le tuteur ; c) en favorisant une manière de réfléchir qui suivrait un processus de recherche collective.

Mots-clé : éducation universitaire, formation initiale des enseignants, aides enseignants, practicum, réflexion collaborative, communautés de pratique.

\section{ERREFERENTZIAK}

Argyris, Ch. eta Schön, D.A. (1978). Organizational learning: A theory of action perspective. Reis. 77, 78-97/345-348. Barcelona: Octaedro.

Berliner, D.C. (1988). Memory for teaching as a function of expertise. American Educational Research Association-en aurkeztutako komunikazioa, New Orleans.

Bolívar, A. (2008). Ciudadanía y competencias básicas. Sevilla: Fundación ECOEM.

Clandinin, D.J. (1986). Classroom practice: Teacher images in action. Philadelphia: The Palmer Press.

Clarà, M. (2015). What Is Reflection? Looking for Clarity in an Ambiguous Notion. Journal of Teacher Education, 66(3), 261-271.

Clarà, M. eta Mauri, T. (2010). El conocimiento práctico. Cuatro conceptualizaciones constructivistas de las relaciones entre conocimiento teórico y práctica educativa. Infancia y Apredizaje, 33, 131-141.

Coll, C., Onrubia, J. eta Mauri, T. (2008). Ayudar a aprender en contextos educativos: el ejercicio de la influencia educative y el análisis de la enseñanza. $R e$ vista de Educación, 346, 333-70.

Contreras, C., Monereo, C. eta Badia, A. (2010). Explorando en la identidad: ¿Cómo enfrentan los docentes universitarios los incidentes críticos que ocurren en las aulas de formación de futuros profesores? Estudios pedagógicos, XXXVI (2), 63-81.

Coombs, S.J. eta Smith, I.D. (2003). The Hawthorne effect: Is it a help or hindrance in social science research? Change: Transformations in Education, $6(1), 97-111$.

Day, C. (2005). Formar docentes. Cómo, cuándo y en qué condiciones aprende el profesorado. Madrid: Narcea.

Day, C. (2006). Pasión por enseñar. La identidad profesional del docente y sus valores. Madrid: Narcea editores.

Delors, J. (1996). La educación encierra un tesoro. París: UNESCO.

Dewey, J. (1986). How we think: A restatement of the relation of reflective thinking to the educative process. In . In J.A.

Dewey, J. (1989). Cómo pensamos. Barcelona: Paidós-Ibérica.

Elbaz, F. (1981). The teacher's «practical knowledge»: Report of a case study. Curriculum Inquiry, II , 43-71. 
Esteve,O. eta Alsina, A. (2010). Hacia el desarrollo de la competencia profesional del profesorado. In O. Esteve., K. Melief. eta A. Alsina (Ed.). Creando mi profesión. Una propuesta para el desarrollo profesional del profesorado. Barcelona: Octaedro.

Fullan, M. (2002a). Las fuerzas del cambio. Explorando las profundidades de la reforma educativa. Madrid: Akal [Change forces. The depths of educational reform. 1993. Londres: The Falmer Press].

Fullan, M. (2002b). Los nuevos significados del cambio en educación. Barcelona: Octaedro [The New meaning of education change. Londres: Teacher College Press Cassell] .

Gelfuso, A. (2016). A framework for facilitating video-mediated reflection: Supporting preservice teachers as they create 'warranted assertabilities' about literacy teaching and learning. Teaching and Teacher Education, 58, 68-79.

Gelfuso, A. eta Dennis, D. (2014). Getting reflection off the page: The challenges of developing support structures for pre-service teacher reflection. Teaching and Teacher Education, 38, 1-11.

Goodwin, A. (2002). Teacher Preparation and the Education of Immigrant Children. Education and urban society, 34-2, 156-172.

Gutmann, A. (1987). Democratic Education. Pricenton. NJ: Pricenton Universty Press (Trad. Cast. La educación democrática. Barcelona: Paidós, 2001).

Hammerness, K., Darling-Hammond, L., Bransford, J., Berliner, D., CochranSmith, M., McDonald, M. eta Zeichner, K. (2005). How Teachers Learn and Develop. In L.

Harford, J. eta G. MacRuairc. (2008). Engaging student teachers in meaningful reflective practice. Teachers and teachers education, 24, 1884-1892

Hargreaves, A eta Shirley, D. (2012). La cuarta vía. El prometedor futuro del cambio educativo.

Hopkins, D eta Lagerweij (1997). La base de conocimientos de mejora de la escuela. In D. Reynoldsm et al. Las escuelas eficaces. Claves para mejorar la enseñanza. Madrid: Santillana.

Hopkins, D. (1996). Towards a theory for School Improvement. In J. Gray et al. (Ed.), Merging Traditions: the future of research on School Effectiveness and School Improvement (pp. 30-51). London: Cassell.

Hord, S.M. (1997). Professional learning communities: Communities of continuous inquiry and improvemen. Austin, TX: Southwest Educational Development Laboratory.

Keow Ngang, T., Shiau Yie, C., Asiah Md Shahid, S. (2005). Quality Teaching: Relationship to Soft Skills Acquisition. Procedía - Social and Behavioral Sciences 191 ( 2015 ) 1934-1937.

Kolb, D. (1984). Experiential Learning. New Jersey: Prentice Hall.

Korthagen, F.A.J. (2001). Linking Practice and Theory. The Pedagogy of Realistic Teacher Education. Londres: Lawrence Erlbaum Associates

Korthagen, F.A.J. (2010). How teachers education can make a difference. Journal of Education for teaching: International research and pedagogy, 36, 407-423.

Krichesky. G.J. eta Murillo, F.J. (2011). Las Comunidades Profesionales de Aprendizaje. Una estrategia de mejora para una nueva concepción de escuela. REICE-Revista Iberoamericana sobre Calidad, Eficacia y Cambio en Educación, 9(1), 65-83. 
Lave, J. eta Wenger, E. (1991). Situated learning: Legitimate peripheral participation. Cambridge: Cambridge University Press.

Liston, Y.S. eta Zeichner, K.M. (1993). Formación del profesorado y condiciones sociales de la escolarización. Madrid: Morata/Paideia.

Macdonald, E. eta Shirley, D. (2009). The mindful teacher. New York: Teacher College Press.

Manouchehri, A. (2002): Developing teaching knowledge through peer discourse. Teaching and Teacher Education, 18, 715-737.

Martinez, A. (2011). Los Servicios de Apoyo como oportunidad para la innovación en el Sistema Educativo. Una propuesta de mejora basada en el análisis del funcionamiento de los Berritzegunes de la CAV 2002-2011. [Doctoregotesia]. Filosofia eta Hezkuntza zientzien fakultatea. EHU.

Mauri, T., Clarà, M., Colomina, R. eta Onrubia, J. (2015). Naturaleza de la interacción en procesos de reflexión conjunta sobre situaciones de la práctica por estudiantes de maestro. Papeles de Trabajo sobre Cultura, Educación y Desarrollo Humano, 11(2), 105-109.

Mauri, T., Clarà, M., Colomina, R. eta Onrubia, J. (2016). Educational assistance to improve reflective practice among student teachers. Electronic Journal of Research in Educational Psychology, 14 (2), 287-309.

Mauri, T., Clarà, M., Colomina, R., Onrubia, J. eta Ginesta, A. (2013). Guiding dialogic joint elaboration of student teacher's situational representations. The 15th EARLI Conference, Munich.

Monereo, C. (2010). La formación del profesorado: una pauta para el análisis e intervención a través de incidentes críticos. Revista Iberoamericana de Educación, 52, 149-178.

Monereo, C. eta Monte, M. (2011). Docentes en tránsito. Incidentes críticos en secundaria. Barcelona: Graó.

Morin, E. (2009). Los siete saberes necesarios para la educación del futuro. Barcelona: Paidós [V.O.: Les sept savoirs nécessaires à l'education du futur. París. Seuil, 2000].

Orcasitas, J.R. (2005). Educación para la ciudadanía y compromiso social. OGE, 60(5), 22-25.

Orland-Barak, L. and Yinon, H. (2007). When theory meets practice: What student teachers learn from guided reflection on their own classroom discourse. Teaching and Teacher Education 23, 957-969.

Pérez, A. (1992). Comprender la enseñanza en la escuela. Modelos metodológicos de investigación educativa. In G. Sacristán eta A. Pérez (1992). Capítulo V.

Pérez, A. (2010). Aprender a educar: Nuevos desafios para la formación de docentes. Revista interuniversitaria de formación del profesorado, 68, 37-60.

Pérez, A., Barquín, J. eta Angulo, J.F. (1999). Desarrollo profesional del docente. Política, investigación y práctica. Madrid: Akal.

Perrenoud, Ph. (1996). Enseigner: agir dans l'urgence, décider dans l'incertitude. Savoirs et compétences dans un métier complexe. Paris : ESF (2. ed. 1999).

Perrenoud, Ph. (2004). Desarrollar la práctica reflexiva en el oficio de enseñar: profesionalización y razón pedagógica. Barcelona: Graó.

Perrenoud, Ph. (2012). Cuando la escuela pretende preparar para la vida. ¿Desarrollar competencias o enseñar otros saberes? Barcelona: Graó. 
Porlán, R. (1987). El maestro como investigador en el aula. Investigar para conocer, conocer para enseñar. Investigación en la escuela, 1, 63-69.

Pozo, J.I., Scheuer, N., Mateos, M. eta Pérez Echeverría, M. del P. (2006). Las teorías implícitas sobre el aprendizaje y la enseñanza. In J.I. Pozo., N.Scheuer., M. del P. Pérez Echeverría., M. Mateos., E. Martín., eta M. de la Cruz. (Edk.). Nuevas formas de pensar la enseñanza y el aprendizaje. Las concepciones de profesores y alumnos (95-132 or.). Barcelona: Graó.

Rivas, J.I., Leite, A.E. eta Cortés, P. (2011). Luchando contra la historia. Educación y Pedagogía, 61,1-20.

Schön, D.A. (1998). El profesional reflexivo: Cómo piensan los profesionales cuando actúan. Barcelona: Paidós.

Schön, D.A. (1987). Educating the reflective practitioner. San Francisco: JosseyBass.

Schön, D.A. (1983). The reflective practitioner. New York: Basic Books.

Stoll eta Louis. (2007). Professional learning communities: Divergence, depth and dilemmas. Berkshire, England: Open University Press.

Van de Pol, J., Volman, M., eta Beishuizen, J. (2010). Scaffolding in Teacher-Student Interaction: A decade of research. Educational Psychological Review, 22, 271-296.

Wenger, E. (2001). Comunidades de práctica. Aprendizaje, significado e identidad. Paidós, Barcelona. [Communities of practice: Learning, meaning, and identity. Cambridge, UK: Cambridge University Press.]

Wertheimer, M. (1971). Productive thinking. New York, Evanston, San Francisco, London: Harper \& Row.

Wideen, M., Mayer-Smith, J., eta Moon, B. (1998). A critical analysis of the research on learning to teach: Making the case for an ecological perspective on.

Yin, R.K. (1989). Case Study Research. Design and Methods. Newbury Park: SAGE. 
